\title{
The Silent Takeover of Power by the Far-Right
}

\author{
Luiz Valério P Trindade* \\ Department of Sociology, University of Southampton, UK
}

Submission: February 12, 2020; Published: February 24, 2020

"Corresponding author: Luiz Valério P Trindade, Faculty of Social Sciences, University of Southampton, UK

Abstract

Within the past decade, the world has been experiencing profound changes and complex challenging events such as, for instance, the global financial crisis, human displacement, and mass immigration. In this context, outsider far-right political figures in Brazil, Italy, and the US have emerged to the central political stage and fostered strong nationalistic political discourses on social media which, rather than weaving integration and solidarity amongst peoples, have been encouraging and endorsing further divisionism.

Keywords: Political discourse; Fake news; Post-truth era; Extreme far-right; Social media

\section{The Silent Takeover of Power by the Far-Right}

Within a timeframe of fewer than ten years, the world has witnessed a significant shift from progressive governments towards the far-right across Europe and several other Western societies [1-2]. Amongst the countries who have made this move, three, in particular, call our attention: Brazil, Italy and the US. The common feature among them is the fact that their respective emerging leaders have brought to the surface quite similar political discourses. Whilst Donald Trump has hailed 'America First', in Brazil, Jair Bolsonaro has fostered the motto 'Pátria Amada Brasil' (Brazil, beloved nation), whereas, in Italy, Matteo Salvini defends 'Prima gli italiani' (First the Italians) [3-5]. More than catchy political slogans, these three analogous discourses reveal a particular world view advocated by the respective political leaders centred mostly on strong nationalistic values. In line with that, these discourses also convey the embedded message of the inauguration of a completely different and contrasting political agenda in comparison to their predecessors. Instead of welcoming and integrationist external policies, their focus has rather shifted primarily inwards. The discourses embed a binary perspective centered on 'us' and 'them', where nationalistic ideals have become predominant above everything else, whereas the needs and demands of the less privileged became secondary or simply disregarded. See, for example, Donald Trump's implementation of stricter immigration policies that have caused the separation of young children from their par- ents [6]. In Brazil, the election of far-right candidate Jair Bolsonaro, rather than uniting an already divided country, has deepened such divisionism [7]. As for Italy, Matteo Salvini had promised to deport at least half a million 'illegal' immigrants claiming that it was meant to tackle the core of the country's social problems [89]. Additionally, it is also relevant to highlight that these political discourses have emerged in the context of the so-called post-truth era, where one of its major characteristics is that critical thinking and standpoints challenging the ideas advocated by far-right political leaders are often framed as 'fake news'. Indeed, in this regard, there are numerous examples where Donald Trump and Jair Bolsonaro have claimed that certain criticisms to their policies were simply 'fake news' and, consequently, delegitimised them [10-11]. Furthermore, this ideology has also fueled the approach to turn political adversaries into enemies, since they do not share similar world views. However, what is usually absent from the debates regarding the recent emergence to power of far-right leaders in several Western societies, is the fact that many people did not notice them arising. Not the civil society, not opinion makers or political analysts, and neither the mainstream political elite in many countries.

Not long ago, these three political leaders were practically outsider figures in their respective countries, whereas nowadays they are either influential voices or the ones setting the tone of the 
political debate and agenda. Within that, it is not difficult to recall that not many people foresaw the real chances of Donald Trump winning the US presidency in 2016 or even the nomination within the Republican Party [12]. In Brazil, it was not that different from the US on this aspect. Although Jair Bolsonaro had served as a congressman for twenty-seven years, initially, his candidacy did not enjoy widespread credibility [7]. Similar to Brazil and the US, in Italy, there were also voices claiming that, most probably, Matteo Salvini would not become such a powerful and influential political figure [13]. Nonetheless, political predictions can always be deceiving, and even electoral projections based on opinion polls are subjected to mistakes or inaccuracy once the ballot boxes are actually opened and the votes counted. But the important fact is that this similar phenomenon of emerging far-right political figures in the three countries reveals that, in fact, society did not fully realize (or gave real credit to the possibility of) their successful endeavor. Indeed, here lays the core issue. Failing to foresee the efficacy of their discourse in establishing strong bonds with voters' expectations or their views of the current political scenario, has proved crucial. Whilst the traditional major players had the mainstream media spotlights directed towards them and, consequently, attracting people's attention, the three aforementioned politicians were making their move to overtake their opponents in the key moment in the electoral race. Moreover, since Barack Obama's successful election in 2008, it should not be new to most political contenders that the internet and social media platforms can play an important and decisive role in the fate of election campaigns [14]. Within that, different from their opponents, the three political leaders (Donald Trump, Jair Bolsonaro and Matteo Salvini) have strongly explored, respectively, the full potential of Twitter, WhatsApp and Facebook to leverage their campaign, spreading the word about their political views and connecting with voters.

However, it cannot be taken out of the equation that the occurrence of certain controversial events might have influenced voters' mindset in regard to both Donald Trump and Jair Bolsonaro campaigns and leading towards their successful election [15]. Eventually, in the absence of these events (i.e. allegedly external influence in the US election and mass dissemination of fake news via WhatsApp in Brazil), the final result could have been considerably different in both countries. The problem is that we will never know and, consequently, we have to deal with the concrete facts rather than with the suppositions. Thus, dealing with the concrete fact that these leaders have been democratically elected, it becomes clear that the rise of far-right political discourse in Western societies might have comprised a phenomenon not fully acknowledged by many people. It also leaves an important hint to progressive political forces across different societies, meaning that underestimating improbable outsider or emerging political figures might not be a good strategy. Therefore, the silent takeover of power by the far-right political leaders in Brazil, Italy, and the US has been characterised, first, by major progressive political forces failing to see them coming. In other words, ignoring the possibility of their victory has represented a big strategic mistake. Second, similar to what Barack Obama successfully achieved in the past, the far-right candidates have been able not only to notice but also to explore the wide array of communication possibilities granted by social media platforms in order to shorten the distance between themselves and the voters to convey their discourse. Finally, the current geopolitical scenario is increasingly challenging and complex. They encompass events such as, for instance, the global financial crisis caused by Lehman Brother's bankruptcy in September 2008, the end of the supercycle of commodities that had boosted the growth of emerging economies, and other global social phenomena such as human displacement and mass immigration in Europe [17-20]. The three political leaders seem to have managed to navigate better in this changing world than their opponents. Most probably, not because they had better solutions to face such challenges, but mainly due to their capacity to articulate discourses that have captured voters' disappointments and converted them into their nationalistic slogans as the solution for voters' anxieties and uncertainties concerning the future.

Nonetheless, one of the major problems with the enactment of this world view is the fact that it increasingly fosters the lifting of strong borders (sometimes even physical and not only based on restrictive laws) as the sole and prime solution to tackle global issues, whereas integration, solidarity and diplomatic dialogue are left behind [21]. As a consequence, we are witnessing not only the silent takeover of power by the far right but also the emergence of increasingly divided societies where the discourse 'us' versus 'them' is becoming prevalent. Furthermore, in a strongly binary world, as have been fostered by many political leaders, very little room (if any) is left for diversity to flourish, for greater cooperation, mutual understanding, acceptance and constructive debates.

\section{References}

1. Fekete L (2017) Europe's Fault Lines: Racism and the Rise of the Right. UK: Verso, London.

2. Muis J, Immerzeel T (2017) Causes and consequences of the rise of populist radical right parties and movements in Europe. Current Sociology 65(6): 909-930.

3. WH (2017) The Inaugural Address. The White House, Washington, US.

4. Melo J KLA (2019) Os 150 dias de governo Bolsonaro: Pátria Amada Brasil. Bolsonaro's first 150 days of administration: "Brazil Beloved Nation, Universidade Federal de Campina Grande. Tecnologia de Gestão Pública.

5. Albertazzi D, Giovannini A, Seddone A (2018) 'No regionalism please, we are Leghisti!' The transformation of the Italian Lega Nord under the leadership of Matteo Salvini, Regional \& Federal Studies 28 (5): 645671. 
6. Holpuch A (2019) Thousands more migrant children separated under Trump than previously known. The Guardian, London, UK.

7. Fonseca JP (2018) Show Me a Hero: Political disillusionment elevates a strongman before Brazil's election. World Policy Journal 35(2): 77-82.

8. Mantovan C (2018) They treat us like criminals': urban public spaces and ethnic discrimination in Italy. Patterns of Prejudice 52(4): 338354

9. Stille A (2018) How Matteo Salvini pulled Italy to the far right. The Guardian, London, UK.

10. Wemple E (2018) Not praising Trump enough is now 'fake news', The Washington Post, Washington, US.

11. Kirby J (2019) Jair Bolsonaro says Brazil and the US stand side by side "against fake news", Vox, New York, NY.

12. Smith DN, Hanley E (2018) The Anger Games: Who Voted for Donald Trump in the 2016 Election, and Why? Critical Sociology 44(2): 195212

13. Wallace K (2018) Could Salvini be Italy's next PM? La Repubblica, Rome, Italy.

14. Cogburn DL, Espinoza-Vasquez FK (2011) From Networked Nominee to Networked Nation: Examining the Impact of Web 2.0 and Socia Media on Political Participation and Civic Engagement in the 2008 Obama Campaign, Journal of Political Marketing 10(1-2): 189-213.
15. Collinson S (2019) Trump's Putin problem seizes the spotlight in a time of turmoil, CNN, Atlanta, GA.

16. Abdin L (2019) Bots and fake news: the role of WhatsApp in the 2018 Brazilian Presidential election, Paper presented at Intersection | CrossSections: Graduate Conference \& Art Exhibition, Ontario, Canada.

17. Chu B (2018) Financial crisis 2008: How Lehman Brothers helped cause the worst financial crisis in history. The Independent, London, UK.

18. Büyükşahin B, Mo KM, Zmitrowicz K (2016) Commodity Price Super cycles: What Are They and What Lies Ahead? Bank of Canada Review, Autumn, Toronto, Canada, pp. 35-46.

19. UNESCO (2019) Migration and inclusive societies, UNESCO, New York, NY.

20. Guterres A (2015) Global conflicts and human displacement: $21^{\text {st }}$ Century challenges, delivered by António Guterres, UN High Commissioner for Refugees, UNHCR - The UN Refugee Agency, Geneva, Switzerland.

21. O’Connell G (2018) Pope Francis: 'Build bridges, not walls', America Magazine, New York, NY.

Your next submission with Juniper Publishers
will reach you the below assets
- Quality Editorial service
- Swift Peer Review
- Reprints availability
- E-prints Service
- Manuscript Podcast for convenient understanding
- Global attainment for your research
- Manuscript accessibility in different formats
( Pdf, E-pub, Full Text, Audio)
- Unceasing customer service
Track the below URL for one-step submission
https://juniperpublishers.com/online-submission.php

